\title{
最近の新聞用インクと新聞用塗工剤の技術動向
}

\author{
ハリマ化成株式会社技術開発部第二グループ 石 井 和 広
}

\section{The Trend of News Ink and Coating Agent for Newsprint}

Kazuhiro Ishii

Research \& Development Dept., Harima Chemicals, Inc.

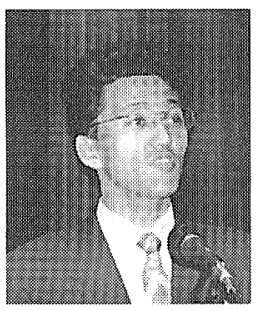

Newsprint production is made advanced high speed printing and reduction of labor for the purpose of productivity improvement. From the viewpoint of the environmental issue, the news ink with aromatic free solvents are developed.

The improvements of water repellency and surface strength are required to newsprint for off-set printing with super-light-weight paper or for high speed printing.

In almost all newspaper mills, gate roll coaters are generally installed. Specially the use of poly acryl-amide (PAM) coating agent is spreading. We propose the newly gate roll coating agent with excellent surface strength as well as high water repellency.

Keywords: newsprint, news ink, off-set, water repellency, surface strength, gate roll, poly acryl amide

\section{1.はじめに}

近年の新聞印刷は生産性向上のため高速化，省人力 化が進んでいる。それに加え，環境保護問題から，有 害物質の少ないインクの開発が進められている。現在, 新聞インクの動向としては環境に優しく, 連続操業・ 高速印刷下で安定であることをポイントに各社開発を 進めている。

一方, 新聞用紙の面からも超軽量化, キーレス印刷 の普及，印刷の高速化に伴う表面強度の向上がポイン 卜となる。新聞用紙は高速, 高温抄造されて扮り一般 的な内添サイズ剤, 塗工郕では問題がある。

このような状況下，新聞用紙抄造ではゲートロール 塗工が一般化しており，塗工剈はポリアクリルアマイ ド (PAM) 系が普及しつつある。印刷方式のオフセ
ット印刷への移行に伴い塗工剤には表面强度だけでな くサイズ性も求められている(表 1)。

そこでこのような技術動向に対し，印刷インク用樹 脂ならびに新聞抄造用薬品の両方から検討を進めてい

表 1 新聞用紙の課題と対応

\begin{tabular}{l|l|l}
\hline \multicolumn{1}{c|}{ 課題 } & \multicolumn{1}{c|}{ 新聞用紙 } & \multicolumn{1}{c}{ 新聞印刷 } \\
\hline 環 境 対応 & 占紙の利用 & $\begin{array}{l}\text { インクの } \mathrm{AF} \text { 化 } \\
\text { VOCの低減 }\end{array}$ \\
\hline 品質 向上 & ゲートロール化 & $\begin{array}{l}\text { カラー化 } \\
\text { オフセット化 }\end{array}$ \\
\hline 生産性向上 & ゲートロール化 & 機上安定性 \\
\hline 省 カ 化 & 軽量化 & キーレス印刷 \\
\hline
\end{tabular}


ることについて述べる。

\section{2. 新聞用紙の動向}

\section{1 市場 動 向}

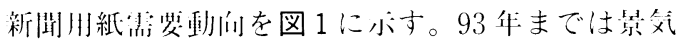

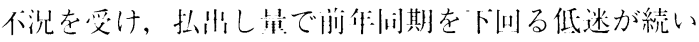

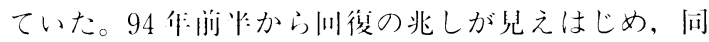
作後政仪びを小しフラス側に転じてきた。これは

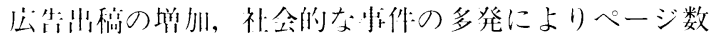
が增えたことが大きいと推祭される。

\section{2 軽 量 化}

新閉川紙は輸送コストの低娍老川的に怪星化が進ん

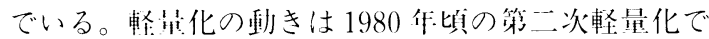

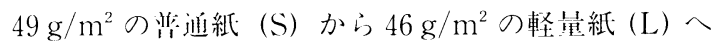
の移行で见られた。ついで1989作頃の第三次軽量化 で $43 \mathrm{~g} / \mathrm{m}^{2}$ 超軽䧃紙 (SL) へと移っている。図 2 に

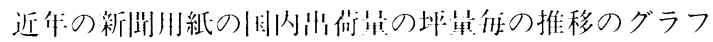
を小卞。1990俳台に入ってから急速に超軽望紙へ上 推移しており，95 作（〕测）には84\%が超軽量紙とな

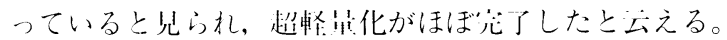
次の段階としてさらに軽虬化された $40 \mathrm{~g} / \mathrm{m}^{2}$ の超々 軽早紙へと移ろうとしている。

\section{3 印刷方式}

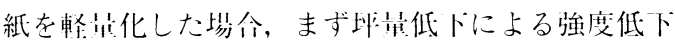
が考えられるが，代透㺫度の低トも大きな閵題となっ

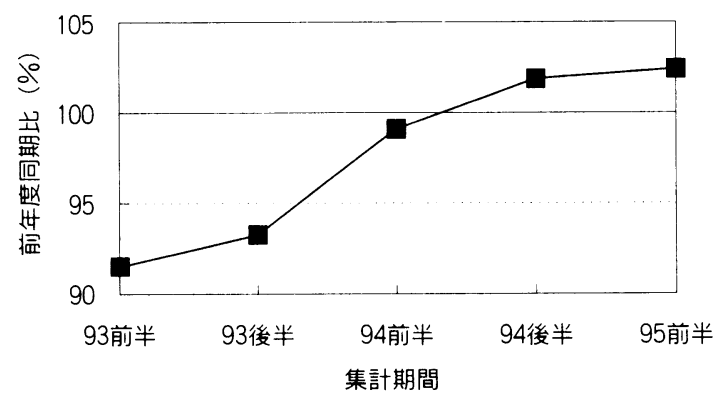

図 1 新椡肋紙哲紧動们

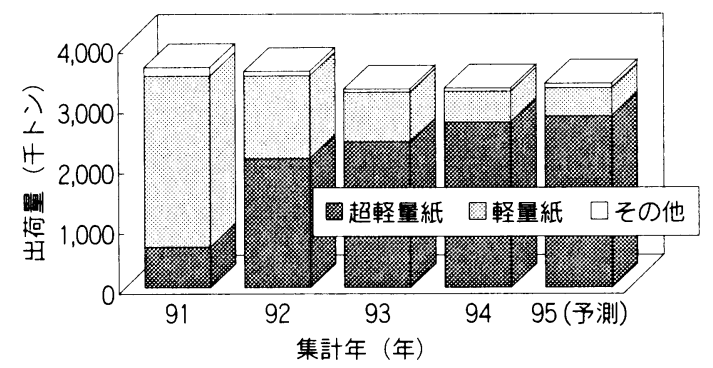

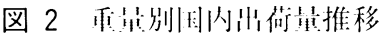

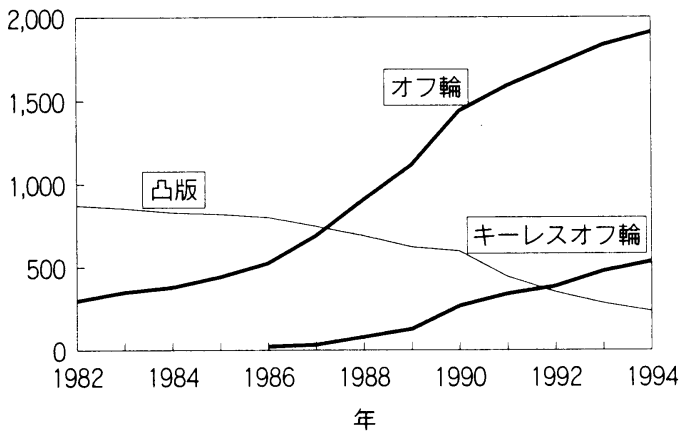

図 3 新聞輪転機台数の推移（単位：台)

てくる。特に印刷後のインクの桽抜けは新聞紙上して の品質低下を意味する。

そこで新聞用紙の軽量化の動きと间時に，インクの 裹拔け対策としてインクの浸透の少ない㓝别方式，卵 ちオフセット印刷が必要となってくる。

図 3 に新聞輪転機台数の推移を小寸。従来の川版輪 転機に対しオフセット輪転機の著しい增加が一川で理 解できる。1994 年には輪転機台数べースでのオフセ ット化率は89\%に達している。このことからも超軽 量紙化はほぼ達成されていると理解して良い。卵制 方式が凸版輪転からオフセット輪転に変化してきたが, 新聞社からのニーズとして特に広告などのビジュアル 化をはかるための紙而のカラー化, 記本の最新化を刚 るための印刷丁場の分散化も间時に進行している。こ れにともない印刷の省力化を目的とした自動化，问速 化を進める必裂がある。特に省力化についてはキーレ スオフセット印刷化が進んでいる。网３にみられる 1980 年中頃からキーレスオフ輪機が登場し，その後 も順調に增加している。

キーレス印刷はインク調整ボタン（キー）がないた

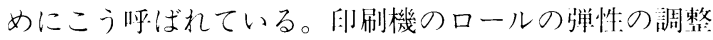
等のハード技術は車要であるが，オペレーターサイド からみれば装置が単純構造であるた仯打，少人化に は住用であり令後も增加していくもの上思わ机る。

\section{3. 印刷インク}

\section{1 インク組成}

印刷インクは主剆となる顔料とビヒクル，助剂とな る齐種添加戍からなっている。ビヒクルの構成は図 4 に亦すような溶剤成分上樹脂成分からなっている。

インク用樹脂には大然樹脂や硬化ロジンに代衣され る天然樹脂誘導体，フェノール樹脂に代表さ机る命成 樹脂等がある。

また図 5 に示すように少社ではロジンを原料とした 


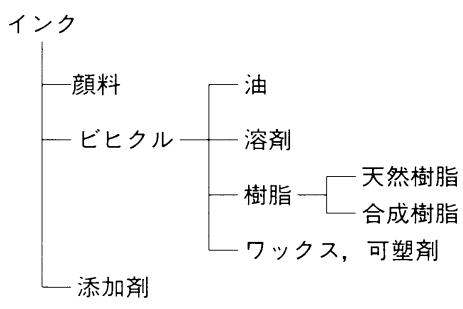

図４亿ンク組成図

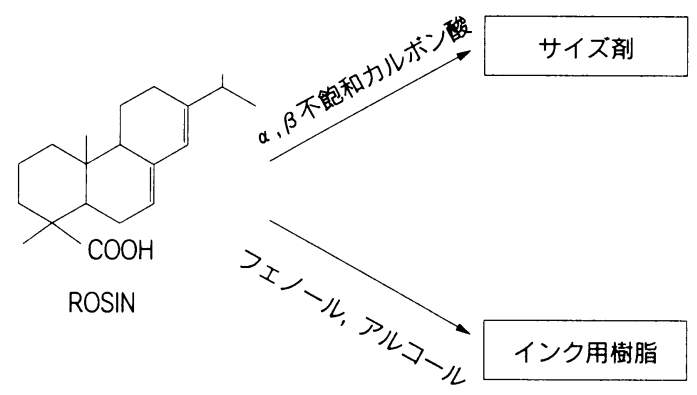

図 5 ロジンからの製品

サイズ剤やインク用樹脂を提供している。

表 2 に各種インクの代表的な組成を示す。新聞用イ ンクは樹脂分が少なく溶剤としてスピンドル油などの 鉱物油を用いている。乾燥は溶剤の紙中への吸収で進 行するクイックセットタイプとなり，その粘度は平版 のなかでは最も低いものとなる。

\section{2 環境対応}

印刷インク業界においては近年の地球規模での環境 保護の動きに対応している。米国では OSHA (米国労 働安全衛生局)による溶剤に関わる規制や EPA（米国 環境保護庁）によるVOCs（揮発性有機化合物）規制 が実施されている。国内に打いては労働安全衛生法, 消防法の強化に加え, 製造物責任 (PL) 法, MSDS の提出など安全性確保に関する規制が整ってきた。

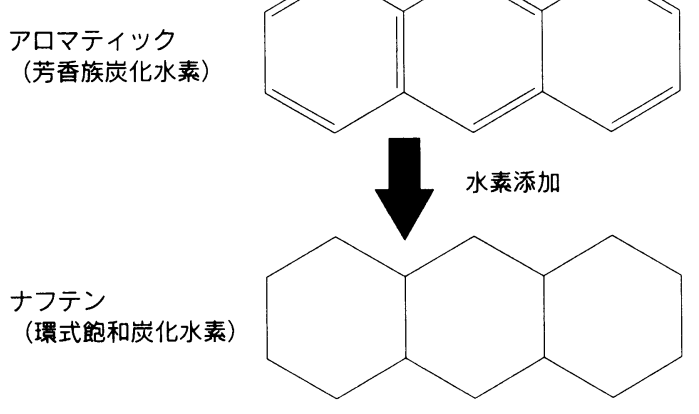

図 6 溶剮成分の構造

このような状況下 1991 年に日本不油懒から安全性 の高いアロマフリー (AF) ソルベントが発売された。 発ガン性物質であるという指摘を受けな芳香族成分を $0.5 \%$ 以下にした溶剤である。AFソルベントの登場 によりインク業界においても環境対応の気連が高まっ ている。アロマ成分を水素添加処理する事により発が ン性はもとより臭気や皮獻刺激性の少ないナフテン系 の溶剤となっている(図6)。

しかしながら，同時に溶剈の物性の相違が発生する ため, $\mathrm{AF}$ 溶剤に合ったインク用樹脂の設計が必要で ある。

図７にAFソルベントと従来の No.ソルベントの アロマ分とアニリン点のデータを示す。AFソルベン 卜はアロマ成分が極めて少なく環境に対応した溶凨で あるといえるが, No.ソルベントに比べてアニリン 点が高い。アニリン点は樹脂の溶解性を反映する数值 であり，アニリン点が高い AFソルベントはNo、ソ ルベントに比べて樹脂の溶解性が低い事をボしている。

\subsection{AFソルベントを用いたインク}

AFソルベントを用いた新聞用インクが開発された としても従来と同じ印刷機を使用するのであるならば,

表 2 各種インクの組成比較

\begin{tabular}{|c|c|c|c|c|}
\hline & 新聞インク & オフ輪 & 枚 葉 & グラビア \\
\hline 顔料 & 16 & 25 & 25 & 10 \\
\hline 樹脂 & 8 & 30 & 30 & 30 \\
\hline 溶剤 種類 & 鉱物油 & \multicolumn{2}{|c|}{ 高沸点石油系溶剤 } & 低沸点石油系 \\
\hline 量 & 76 & 30 & 15 & 55 \\
\hline 乾性油 & - & 10 & 25 & - \\
\hline 添加剂 & - & 5 & 5 & 5 \\
\hline インク粘度（PS） & $4-50$ & $10-100$ & $100-500$ & $0.5-2$ \\
\hline
\end{tabular}




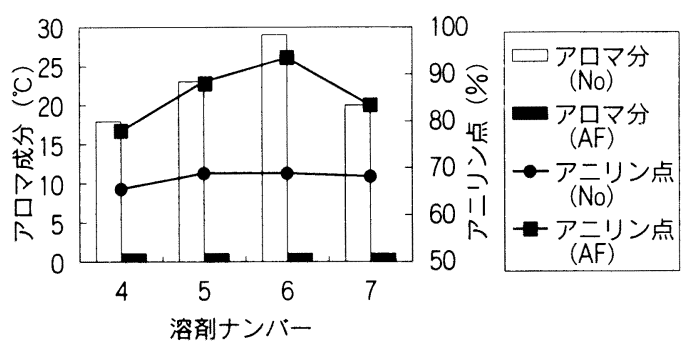

図 $7 \mathrm{AF}$ と No.ソルベントの比較

表 3 溶剂䄻によるインクへの影響

\begin{tabular}{|c|c|c|}
\hline Itill & $\mathrm{AF}$ インク & Noインク \\
\hline 光 沈 & 3 & 5 \\
\hline 乹＼cjkstart燥 & 5 & 3 \\
\hline 耐乳化性: & 5 & 4 \\
\hline ミスチング & 5 & 4 \\
\hline 粗 悭 & 220 & 180 \\
\hline
\end{tabular}

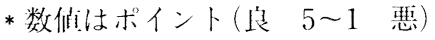

*粘度は代伐估(POISE)

タック，フローなどの見掛けトの物性は現行のインク とほぼ间等のものである必要がある。表 3 に溶㓣種に よるインクへの影聯についてふした。

ここでは淕剂を AFソルベントとNo、ソルベント を朋いて，それ以外は间じ組成でインクを調製してい る。表 3 に小寸ように $\mathrm{AF}$ ソルベントを用いな場合 には漁解性の低トにより粘度がトがりやすくなる。し かしながらミスチングポイントのト昇に見られるよう

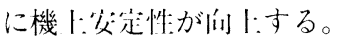

\section{4 インク動向}

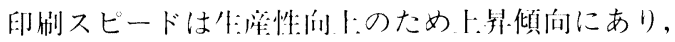
新聞では $600 \mathrm{~m} /$ 分にまでに多している。印刷が高速 化した埸令にはインクにかかる則断力も堌加するため,

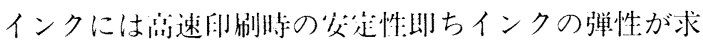
められる。インクの弾性ノの占卜には樹脂の高分子量

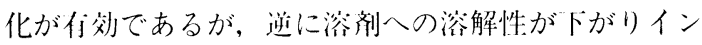
クの粘度が卜多しがちである。そこで近年のオフ輪イ ンク用樹脂には宫分了早でありながら，高い溶解性と なるものが求められている。数华前までは 5 万前後の 分子量を持つものがほ流であったが，ここ数年は 10 厅以以トのもへと移っている(図 8)。分子量, 溶解 性の琵なる樹脂を川いてオフセットインクの代表的な 処方でインクを眮整した。インクB（重量浐均分子量

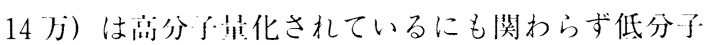

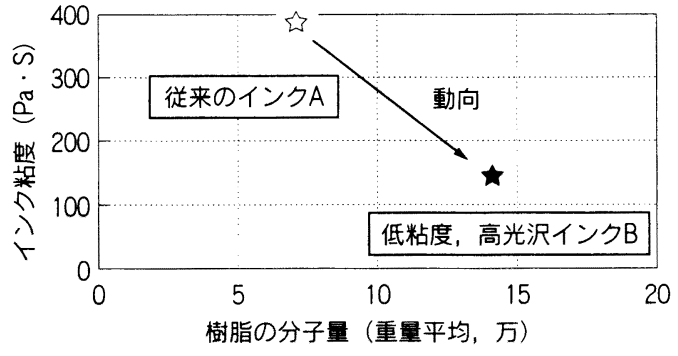

図 8 インク動问

量のインクA（重量平均分子量 7 万）に用いられて いる樹脂よりも高い溶解性を示すため粘度の低下，光 沢の向上が見られる。また耐乳化性の向上によりオフ セット印刷時の安定性に優れるものとなる。

3.5 カラーキーレス

キーレス化が進む中, 紙面のビジュアル化に対応し たカラーキーレス化も進行しつつある。カラーキーレ スオフ輪印刷をした場合, 各色の画線領域が小さいた めに湿し水の量が多くなり，インクパン内の乳化率が 高くなりやすく過乳化状態に陷りやすい。インクが過 乳化すれば，インクの夕ックや粘度の変化, 版の污れ などを生じる。カラーキーレス化に対応していくには 乳化率の安定した樹脂の設計が重要な課題となってく る。

\section{$3.6 \mathrm{VOCs}$ 対策}

米国ではVOCs 規制に対して大豆油などの植物油 の利用が奨められているが (表 4), 日本においては 規制の解勫の違いや表に示したようなコスト閏題等が あり大豆油への移行は進んでいない。

表 4 溶剂価格の日米比較 (1995 年 8 月現在)

\begin{tabular}{ccc}
\hline & 日本 & 米国 \\
\hline 石油系溶剂 & 172 & 100 \\
ア 二 油 & 280 & 247 \\
大 豆 油 & 306 & 208 \\
\hline
\end{tabular}

* : 指数比較

\section{4. 新聞用紙}

\section{1 技 術 動 向}

新聞用紙の技術動向としては以下のような事があげ られる。 


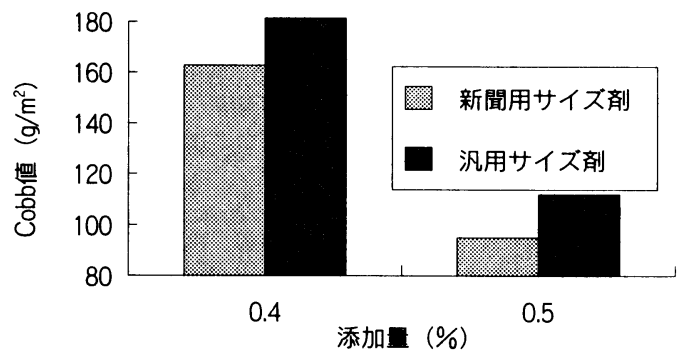

図 9 新闒用サイズ剂の效果

\section{- 環境保護 \\ ・輸送コストの低減 : 古紙リサイクルの推進 \\ ・マシーンの高速化 : 超々軽量化 $\left(40 \mathrm{~g} / \mathrm{m}^{2}\right)$ \\ ・オフセット印刷対応：サイズ性, 耐ネッパリ性}

古紙のリサイクルは1994集までに沾紙叫收摔を 55\%に引きトげる「リサイクル 55 㖕再」が木達に終 わっているが，2000 年までに古紙仙收制を $56 \%$ まで 引きトげる運動で現在も継続している。

古紙利用の增加に伴い原料品質の低卜は避けられず, これを補う為にも種々の内添楽品，豖丁薬㟧がある。 新聞用紙は高速・高温抄造であるためパルプや薬品の 歩留りが悪くなる傾向にあり新聞抄造系にあった楽品 の設定が必要である。例えば新聞用のエマルション サイズ剤ではエマルションの粒一径や反応性をコント ロールし，新聞抄造系で效果が発揮されるように設壈 されている（図9）。高速化に刘忍したゲートロール 塗厂機の設置を各製紙会社とも進めており，大手製紙 メーカーでは全ての新聞肺マシーンに GR 塗「機が没 置されている。

\section{2 超々軽量化}

坪量 $43 \mathrm{~g} / \mathrm{m}^{2}$ の超軽量化から $40 \mathrm{~g} / \mathrm{m}^{2}$ の超々軽易 化への移行の際には, 紙粉や袈抜け, コシの低トとい つた開題が予想される。集拔けに対してはタルクやカ オリンといった一般的な塡料ではなく比散乱係数の南 いホワイトカーボンの使用が必要となる。一j，紙粉 やコシの低トといった開題に対しては紙力剤だけでな

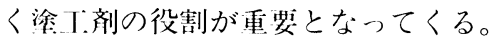

\section{3 ゲートロール (GR) 塗工剤の利用}

新聞用インクは溶剂の紙中への淕透と強制加熱によ り乾燥するクイックドライタイプであり，タックは他 のインクに比べて低く設定してある。しかしながら紙 の表面強度が弱ければ印刷時に紙ムケが起こったり, 紙粉などがヒッキーの原团となったりする。これらの 問題を解決する日的で GR 涂1:棛が利用されている。

図10は白家変性澱粉 (TCS) と PAM 系涂 I: 剂

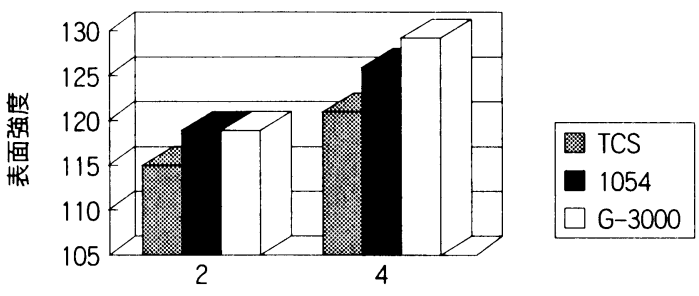

澱粉塗工濃度 $(\%)$ *GR汫は澱粉の $1 / 2$ 濃度

図 10 GR 涂I:による表泊強度への效果 (木涂に紙に対する指数)

「ハリコート1054」「G-3000」を塗I:した紙の依面方強 度のは多の程度を原紙に対する指数でグラフ化したも のである。グラフにあるように GR 塗I剂の使川によ り衣泊強度を们、ささせるとが叮能である。表垧強度 の问、は紙粉を低卜させ，キーレスのような少力化や

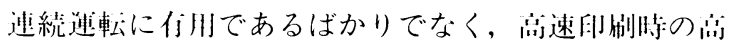

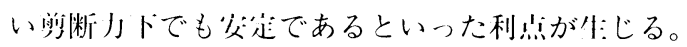

\section{4 オフセット印刷への対応}

オフセット印别は版㭣からゴムブランケットヘイン クがオフされた後セットされる。洅線部を㺫瞭にする 川的で通常アルコールが入った湿し水が使肞されてい る。オフセット印制への移行に伴い，新開川紙には湿 し水に対する耐水性が必要となってくる。カラー印渆 に対しては耐湿し水性の装求はさらに強くなってくる ものと思われる。

しかしながら，新䦌用の内添サイズを用いても监独 ではその效果は仆卜分であり，添加最を增加すると新

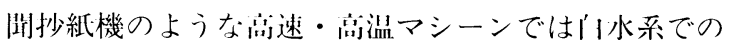
泡の间題が生じる。さらに沨用のスチレン/マレイン 酸其尔命休やスチレン/アクリル其禹命体などの衣陑 サイズ戍を適用しても，通常行われる GR 涂I:では紙 屏への洨透が代小分でサイズ效果の発现は弱い。そこ

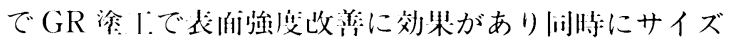
性にも效果のある楽品が望まれている。当社に扔いて は衣陑強度だけでなくサイズ性にも效果がある新規の GR 塗I:剂を尣成しつつある。図 11 に開発を進めて いる新規の涂 I剂の性能を小方。

刚11に小寸ように従米の塗济でも港粉に比べて 衣垍強度は大きく收善されている。しかしながら，サ イズ性に扔いては本涂「紙や測粉徐「紙と比べて多ど

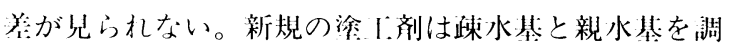
整することにより衣而強度だけでなく婄いサイズ性も 令現している。

\section{5 インク溶剤と印刷適性}

環境刘心型のインク浴剂を月いたインクによる新䦌 


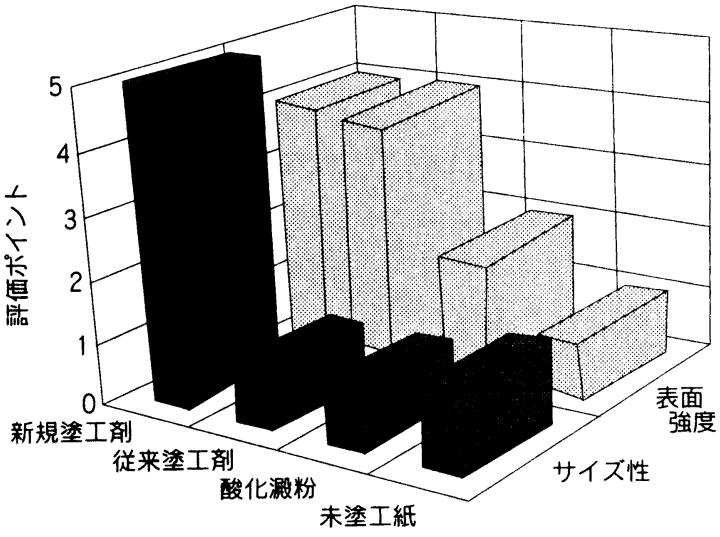

図 11 サイズ性效果のあるGR 涂l剂

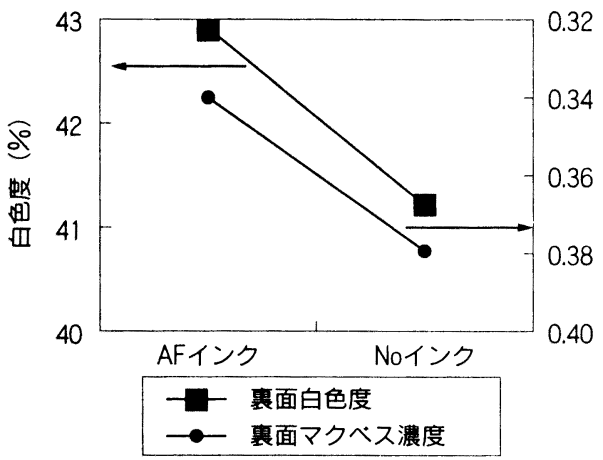

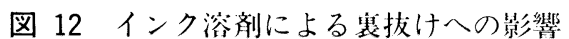

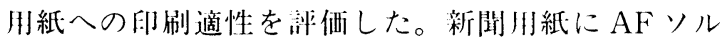
ベントとNo.ソルベントを羘いたインクでその他の 成分は敬力闹様にし， $30^{\circ} \mathrm{C}, 400 \mathrm{rpm}$ の条件で夕ック 俻を 5 に㖓し，フローも同じになるように调整した インクを新聞用紙に印刷した。㵋剂の造いにより紙内 部への浴剂の淩透状態が变化するために斑抜けへの影

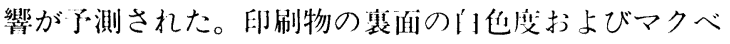
ス濃度（埋）を测定し，裹抜けへの指噤とした。図 12 に门色度およびマクベス值の結果を小す。 $\mathrm{AF}$ ソ ルベントを用いたインクではNo.ソルベントを用い なインクに比べて裹㓦のけ色度が奌く，マクベス濃度 が低いことより，裹拔けが起こり難くなっていること をホしている。これはAFソルベントの斿が溶剤放 れが速いためであると推祭される。

\section{6 塗工凨と印刷適性}

印刷インクの項で述べたようにインクの浴剂種が変 われば被印刷体〜ここでは新閉肞紙〜に刘する物性の

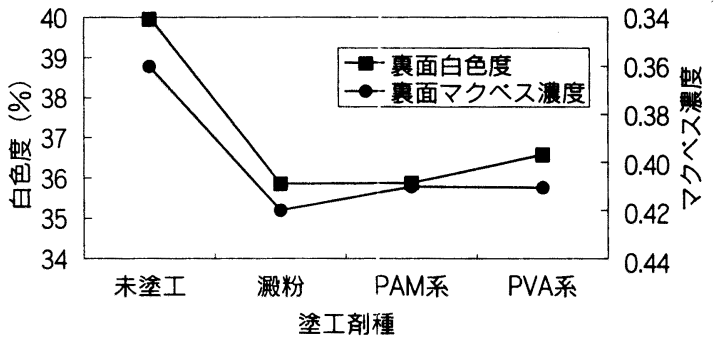

図 13 塗剂種による裏抜けへの影響

変化は必須であり，インクの変化に対する紙の設計, さらには塗工薬品の設計が必要となってくる。図 13

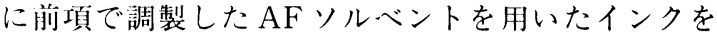
新聞原紙および各種塗厂郕を塗工した紙に印刷を行い, 闹様の才法で裏抜けの程度を評価した結果を示す。

インク溶剤の変更では AFソルベントへの移行に より裏拔けの減少が見られたが, 澱粉, PAM 系, PVA 系いずれの塗丁剂を用いても未塗工紙に比べて 的色度の低下，マクべス濃度の上昇が見られた。これ は条種塗丁紙が未塗厂紙に比べて裏抜けが多く起こつ

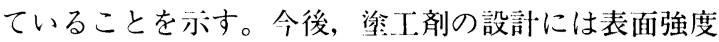
だけでなく，種々の印刷適性を考虑して設定を行って いく必要がある。

\section{5. おわりに}

新聞用インクは高速化と環境に対応した物性を有す る必要がある。実際には溶解性が高く, 乳化率の安定 した樹脂設計が要求される。

新聞用紙は軽量化とそれに伴うオフセット印刷やビ ジュアル要求に対するカラー一化の増加により, 表面強 度だけでなくサイズ性も求奴ている。内添薬品で は卜分に效果を発揮できない新聞用紙ではゲートロー ル塗T.棛による性能の改良が必須である。

さらに今後の塗T.棛の課題としては, 塗工紙の紙質 だけでなく印刷物の光沢や亥抜けなどの状態を改善で きる薬品が必要である。

\section{参考資 料}

1）ヤノレポート 1994 年 10 月 10 日号 P.3

2）ヤノレポート 1995 年 12 月 10 日号 P.57

3) FUTURE 1995 年 12 月 11 日号 P.10

4）印刷界 1995 年 9 月号 P.34

5）印刷インキの技術 シーエムシー刊 